\title{
Status oraz tradycje wychowawcze frankońskich matres familias na przykładzie Herchenefredy (VII wiek) oraz Dhuody z Septymanii (ok. 803-843)
}

Niniejszy artykuł podejmuje problematykę dotyczącą pozycji rodowej oraz uprawnień wychowawczych, które na drodze wielowiekowej tradycji stały się udziałem frankońskich arystokratek. Owe zacne i poważane matrony, podlegające bezwzględnej władzy swych mężów, a także reprezentujące naturalny sexus inferior, posiadały, jak się okazuje, swoistego rodzaju pełnomocnictwo do zabrania otwartego głosu w sprawie moralnego wychowania własnych synów i następców. Kobiety te uzyskały status chrześcijańskich matres familias. Nie brakowało im przy tym przekonania o pełnionej dla dobra całego rodu misji. Z okresu państwa frankońskiego zachowały się dwa pisemne świadectwa tzw. matczynych zmagań wychowawczych. Unikatowe dowody macierzyńskiego trudu, który stawał się ofiarą złożoną Bogu. Reprezentująca początek VII wieku Herchenefreda pozostawiła dla swojego syna Dezyderiusza trzy pouczające listy ${ }^{2}$. Dhuoda z Septymanii, żyjąca w połowie IX wieku, spisała z kolei długi wzorcotwórczy traktat poświęcony prawemu życiu, który zaadresowała do pierworodnego syna Wilhelma.

Zachowane instrukcje wychowawcze Herchenefredy oraz Dhuody poświadczają, jakie były oczekiwania społeczne względem frankońskich matron. Okazuje się, że ponosiły one wielką odpowiedzialność za przekazanie swoim dzieciom moralnych idei oraz praktyk. Tym samym zaj-

Dr Małgorzata Chudzikowska-Wołoszyn, adiunkt w Pracowni Historii Starożytnej i Kultury Antycznej w Katedrze Historii Powszechnej w Instytucie Historii Uniwersytetu Warmińsko-Mazurskiego w Olsztynie, e-mail: m.chudzikowska@uwm.edu.pl, ORCID: 0000-0001-5631-7259.

2 Istnieje spore prawdopodobieństwo, że Herchenefreda wysłała więcej listów do Dezyderiusza, z których zachowały się niestety jedynie trzy. 
mowały ważną rolę $\mathrm{w}$ budowaniu potęgi rodu swoich małżonków. Oba kobiece świadectwa w szczegółowy sposób dostarczają nam dzisiaj odpowiedzi na pytania związane ze statusem ówczesnych matek - rodzicielek merowińskich i karolińskich rodów. W artykule autorka podejmie próbę przybliżenia definicji frankońskiej mater familias, na którą oprócz pradawnej tradycji plemiennej składała się niewątpliwie także zaadoptowana pedagogia patrystyczna.

\section{Koleje życia oraz napominająca twórczość Herchenefredy}

Około 630 roku arystokratka Herchenefreda, żona Salwiusza należącego do wielkiego galorzymskiego rodu Syagriuszy, napisała niezwykle emocjonalne w swej wymowie listy do ukochanego syna Dezyderiusza (ok. 590-655), który w tym samym roku powołany został na stanowisko biskupa Cahors w akwitańskim rejonie królestwa Merowingów. Życie Herchenefredy przypadło na moment dość przełomowy dla całego państwa Franków. Początek VII wieku przyniósł wreszcie względną stabilizację po trwających prawie sto lat zaciekłych wojnach domowych. W 613 roku władzę w całym królestwie przejął Chlotar II (zm. 629). To wówczas wywodzący się z wpływowej frankońskiej arystokracji Dezyderiusz, najmłodszy syn Herchenefredy, postanowił zbliżyć się do królewskiego dworu. W karierze urzędniczej niewątpliwie dopomogło mu, prócz szlachetnego pochodzenia, dobre wykształcenie w zakresie literatury oraz prawa rzymskiego, które, jak można założyć, odebrał w rodzinnej Akwitanii ${ }^{3}$. Rozpoczął od funkcji skarbnika u boku króla Chlotara. Ta sytuacja miała się zmienić około 630 roku, gdy zamordowany został jego brat Syagriusz pełniący urząd zarządcy Marsylii ${ }^{4}$. Dezyderiusz zgodnie z decyzją władcy objął pozostawione przezeń stanowisko. Wkrótce później w wyniku kolejnego brutalnego mordu śmierć poniósł drugi z synów Herchenefredy Rustyk, który w owym czasie był biskupem Cahors. Społeczność miasta uznała, że najlepszym następcą Rustyka będzie ostatni z żyjących braci - Dezyderiusz.

Jeszcze przed 630 rokiem Herchenefreda wysłała do Dezyderiusza trzy adhortacyjne listy. Pierwsze dwa z nich napisała najprawdopodobniej tuż przed śmiercią Rustyka i Syagriusza, w czasie gdy Dezyderiusz realizował się jeszcze w roli doradcy i zarządcy na królewskim dworze. Atmosfera

3 Vita Desiderii Cadurcae urbis episcopi 1, red. B. Krusch, MGH, SS rer. Merov. 4, Hannover 1902, s. 563-564.

4 B.W. Hozeski, Herchenefreda, w: An Encyclopedia of Continental Women Writers, t. 1, red. K.M. Wilson, New York - London 1991, s. 550. 
towarzysząca tej korespondencji nie zdradza bowiem jeszcze matczynego cierpienia i lęku o ostatniego żyjącego spadkobiercę. Emocje te dominują $\mathrm{z}$ kolei w trzecim wysłanym do syna liście.

Należy zaznaczyć, że omawiane epistolograficzne źródło jest jedynym zachowanym $\mathrm{w}$ dobie merowińskiej pismem napisanym przez świecką arystokratkę. Niestety, brakuje nam szczegółowych informacji dotyczących życia oraz pochodzenia Herchenefredy. Kilka drobnych, lecz istotnych wzmianek na jej temat odnajdziemy w powstałym pod koniec VIII wieku życiorysie Dezyderiusza. Czytamy w nim, że matką przyszłego biskupa Cahors była szlachetna i pobożna (honesta et religiosa) ${ }^{5}$ Herchenefreda. Nieco dalej autor zamieścił informację, iż starannym wychowaniem, a także kompletnym wykształceniem Dezyderiusza zajęli się oboje rodzice ${ }^{6}$. Zaakcentowana $\mathrm{w}$ pewien sposób została tutaj niezastąpiona rola wychowawcza zarówno matki, jak i ojca. Biorąc zaś pod uwagę kompletne wykształcenie samego Dezyderiusza, możemy założyć, że Herchenefreda posiadała wszechstronną wiedzę i oczytanie.

Najprawdopodobniej pochodziła ona z regionu południowo-zachodniej Francji ${ }^{7}$ i tam odebrała wykształcenie typowe dla przedstawicieli wyższych warstw społecznych ${ }^{8}$. Lektura listów dowodzi, że znała i posługiwała się poprawną łaciną. Po zawarciu małżeństwa z Salwiuszem trafiła na akwitański dwór w Obrège, któremu nieobca była kultura klasyczna. $\mathrm{W}$ tamtym czasie galo-rzymskie rodziny arystokratyczne wciąż pozostawały w ścisłym kontakcie z rzymską literaturą ${ }^{9}$, retoryką oraz prawem. Dezyderiusz, jak i dwaj jego bracia, odebrał zaawansowane wykształcenie świeckie oraz religijne. Aktywnie zaangażowana w rozwój swoich synów Herchenefreda musiała być zatem kobietą światłą oraz świadomą współczesnej jej kultury i tradycji.

Listy, które arystokratka zdecydowała się napisać do dorosłego już syna Dezyderiusza, wpisują się w nurt komponowanych od V wieku tzw. litterae exhortatoriae, czyli listów napominających. Był to szczególny rodzaj wzorcotwórczej korespondencji, którą duchowni tworzyli przede wszystkim z myślą o władcach. W listach napominających tego okresu

5 Por. Vita Desiderii Cadurcae urbis episcopi 1, MGH, SS rer. Merov., s. 563.

6 Por. Vita Desiderii Cadurcae urbis episcopi 1, MGH, SS rer. Merov., s. 564: „Desiderius vero summa parentum cura enutritus. Litterarum studiis ad plenum eruditus est”.

Por. Hozeski, Herchenefreda, s. 550.

8 Nauczaniem młodych świeckich arystokratów zajmowali się przede wszystkim rodzice, niekiedy uczeni księża lub nauczyciele. Było to kształcenie typowo religijne, które wymagało także rozwinięcia umiejętności pisania i czytania w języku łacińskim.

9 Por. P. Riché, Edukacja i kultura w Europie Zachodniej (VI-VIII w.), tł. M. Radożycka-Paoletti, Warszawa 1995, s. 202, 204. 
odnajdziemy sformułowany $\mathrm{w}$ perswazyjnej postaci zarys nauki o cno$\operatorname{tach}^{10}$, która w rozwiniętej formule znajdzie swoje stałe miejsce w późniejszych zwierciadłach doby karolińskiej ${ }^{11}$. Trudno ustalić jednak, czy Herchenefreda znała i inspirowała się konkretnymi parenetycznymi listami do merowińskich władców. Równie dobrze mogła podążać nurtem bogatej tradycji epistolograficznej, która w państwie Franków intensywnie rozwijała się już od VI wieku ${ }^{12}$.

Pierwsze dwa z listów arystokratki zawierają szereg kaznodziejskich wskazań dotyczących odpowiedniej realizacji chrześcijańskiego życia. Matka Dezyderiusza misję swą nazywała wypełnianiem przyrzeczenia, które dała Bogu. Zachęcała syna, aby nie ustawał w lekturze napisanych z myślą o nim listów. Zależało jej na wyegzekwowaniu od Dezyderiusza, tak korzystnej dla zbawienia jego duszy, pobożnej zachłanności. Wierzyła, że „częste i łapczywe” czytanie jej krótkich, matczynych admonicji skutkuje utrwaleniem ich w sercu i pamięci syna: „Ten list zaś, który przesłałam wam przed czasem, częściej czytajcie i utrwalcie w duszy, zagarnijcie z całą zachłannością umysłu, aby wypełniła się moja obietnica u Boga co do was i poprzez was - słodki synu Dezyderiuszu ${ }^{13}$ ".

Zauważamy, że korespondencja wypełniona została zwięzłymi i stanowczymi w swej wymowie napomnieniami. Najwięcej z nich pojawia się $\mathrm{w}$ pierwszym $\mathrm{z}$ listów. To tutaj, w przemyślanym kompozycyjnie porządku, autorka nakreśliła schemat priorytetów moralnych, którym bezwzględnie powinien być wierny jej syn. Dyktowała, aby nieustannie kierował swe myśli

10 Por. H.H. Anton, Fürstenspiegel des frühen und hohen mittelalters, Stuttgart 2006, s. 11.

11 Do najwcześniejszych przykładów litterae exhortatoriae należy napisany ok. 486 roku krótki konsolacyjny list biskupa Reims Remigiusza do Chlodwiga, merowińskiego króla Franków. Por. Epistolae Austrasicae 1, red. E. Dümmler, MGH, Epp. 3, Berlin 1892, s. 112. Cechy listu napominającego posiada także pismo biskupa Aureliana, (być może chodzi tutaj o Aureliana biskupa Arles), które powstało około 548 roku. Jego autor, posiłkując się panegirycznymi deklaracjami, zapewniał swojego adresata, króla Teudeberta I (wnuka Chlodwiga I), iż tylko cnotliwe życie może stać się drogą do zbawienia. Por. Epistolae Austrasicae 10, s. 125-126.

12 Autorami znanych wczesnośredniowiecznych zbiorów epistolarnych byli Sydoniusz Apolinary (zm. ok. 489), Ennodiusz z Pawii (zm. 521), Rurycjusz z Limoges (zm. po 549), Awitus z Vienne (zm. ok. 520) i wreszcie także sam Dezyderiusz, syn Herchenefredy.

13 Epistolae Herchenefredae, w: Vita Desiderii Cadurcae urbis episcopi, MGH, SS rer. Merov., s. 569-570: „Epistolam vero quam ante tempore vobis direxi sepius legite et animo commendate ac tota mentis ambitione tenete, ut promissio mea de vos aput Deum per vos, dulcis filius Desideri, impleatur" (tł. listów Herchenefredy - M. Chudzikowska-Wołoszyn). 
do Boga. W drugiej kolejności miał okazywać posłuszeństwo i wierność królowi. Swoim towarzyszom winien był zaś zapewnić stałą troskę, pomoc i miłosierdzie. Herchenefreda nie ustawała, aby przestrzegać syna przed złymi uczynkami. Radziła, aby nie tylko sam ich nie czynił, ale również nie wyrażał na nie swojej zgody ${ }^{14}$. Drugi z listów zawierał syntetyczny wykład na temat prawych obyczajów oraz cnót. Arystokratka nakłaniała syna, aby kierował się miłosierdziem oraz był obrońcą i orędownikiem czystości. W każdym swym słowie i czynie, jak zaznaczała, powinien zachowywać przezorność, a na wypadek dopuszczenia się winy gorliwie odprawić pokutę ${ }^{15}$.

Perswazyjny oraz doniosły ton obecny w moralnej retoryce Herchenefredy potwierdzać może jej świadomą realizację wychowawczych obowiązków, które dyktowane były zapewne oczekiwaniami rodzinnymi i społecznymi. Jest bardzo prawdopodobne, że tzw. nobliwe matrony zdawały sobie sprawę z ciążącej na nich odpowiedzialności za moralne i religijne wychowanie swoich dzieci ${ }^{16}$. W podjętym przez nie trudzie, który matka Dezyderiusza nazwała realizacją obietnicy danej Bogu, leżało zbawienie ukochanych potomków. Warto zwrócić uwagę, że Herchenefreda napisała swe instruktażowe listy do prawie czterdziestoletniego syna. Zatem nie uważała ona, ażeby osiągnięcie przez niego samodzielności i dojrzałości miało oznaczać kres jej wychowawczego posłannictwa. Nieprzerwanie odczuwała potrzebę bycia obecną w życiu syna i służenia mu swą niezastąpioną moralną poradą.

14 Por. Epistolae Herchenefredae, s. 569: „Te vero, dulcissimum mihi pignus, moneo, ut assidue Deum cogites, Deum iugiter in mente habeas, mala opera quae Deus odit nec consentias nec facias; regi sis fidelis, contubernales diligas, Deum semper ames et timeas. Ab omni opere per quod Deus offenditur sollicite te custodi, [...]" - "Napominam ciebie zaiste, najsłodszy mi synu, abyś bez przerwy myślał o Bogu, ustawicznie w myślach Boga obejmował, abyś na złe uczynki, których Bóg nienawidzi, ani się na nie zgadzał, ani ich nie czynił, abyś był wierny królowi, abyś troszczył się o towarzyszy i zawsze kochał i bał się Boga. Od wszelkiego czynu, poprzez który Bóg jest obrażany, troskliwie strzeż się, $[\ldots]$.

15 Por. Epistolae Herchenefredae, s. 569: „[...] et quantum potestis, semper pro animae profectu elaborate, caritatem circa omnes tenete, castitatem supra omnia custodite, cautelam in sermone et in omni opere habete, et si forte aliquid mali actum est, cito emendate" - '[...] tak jak możecie, zawsze usilnie pracujcie na rzecz rozwoju duszy, utrzymujcie miłosierdzie wobec wszystkich, strzeżcie ponad wszystko czystości obyczajów, zachowujcie przezorność w słowie i w każdym czynie i jeśli zostanie uczynione cokolwiek złego, szybko naprawcie błędy'.

16 Por. G.W. Olsen, One Heart and One Soul (Acts 4:32 and 34) in Dhuoda's Manual, „Church History. Studies in Christianity and Culture” 61/1 (1992) s. 27; S.F. Wemple, Women in Frankisch Society: Mariagge and the Cloister 500 to 900, Philadelphia 1981, s. 103,125 . 
Omawiając korespondencję Herchenefredy, nie sposób pominąc charakterystycznej dla niej głębokiej emocjonalności. Okazuje się, że arystokratka każdorazowo zwracała się do dorosłego już syna słowami pełnymi troskliwości i czułości. Nazywała go „najdroższym, najsłodszym i najukochańszym” (dulcissimus et amantissimus) ${ }^{17}$, a także „,najbardziej upragnionym" (desiderantissimus) ${ }^{18}$. Dostojnego potomka określała także nietypową formułą pignus, którą można interpretować jako dowód wzajemnej miłości małżeńskiej, a także skarb ${ }^{19}$.

Komponując swoje pismo, autorka musiała zdawać sobie sprawę, że w kontekście utrwalonego przez tradycję prymatu ojca, jak i mężczyzny należącego do klasy nobiles et primores, sam jedynie status niewiasty przedstawicielki słabszej i podrzędnej płci - nie wystarczy, aby spisane przez nią wskazówki mogły nabrać pożądanej mocy i posłuchu. Odwołała się zatem do rangi i pozycji, którą posiadała jako matka arystokratycznego rodu. Możemy wnioskować więc, że ta podwójna rola (matki oraz wychowawczyni) przydawała frankońskim matronom autorytarnego dostojeństwa. W ten sposób osiągały one status chrześcijańskich matres familias, które wespół z mężczyznami podejmowały formacyjny trud nad wychowaniem swoich szlachetnych dziedziców.

\section{Dhuoda z Septymanii i jej intymna instrukcja}

Dla rozważań na temat ciągłości frankońskich tradycji wychowawczych niezwykłe znaczenie ma fakt, iż dwieście lat po Herchenefredzie po-

17 Por. Epistolae Herchenefredae, s. 569: „Dulcissimo atque amantissimo filio Desiderio Herchenefreda”. Epistolae Herchenefredae, s. 570: „Semper desiderabili et dulcissimo filio Desiderio Herchenefreda misera mater".

18 Por. Epistolae Herchenefredae, s. 569: „Dulcissimo et desiderantissimo filio Desiderio Herchenefreda". Matka, nazywając syna najbardziej upragnionym (desiderantissimum), nawiązywała poprzez celową grę słowną do znaczenia jego imienia - Desiderius.

19 Por. Epistolae Herchenefredae, s. 569: „Te vero, dulcissimum mihi pignus, moneo, [...]" - 'Napominam ciebie zaiste, najsłodsze mi dziecko [skarbie]'. Por. także: Epistolae Herchenefredae, s. 570: „Sed tu, piissime pignus, mihi dulcissime, sic te iugiter praecave, [...]" - 'Lecz ty, najbardziej bogobojne dziecko [skarbie], najdroższe mi, zawsze miej się na baczności, [...]'. Termin pignus wywodzi się z łaciny starożytnej i tłumaczyć go można jako 'zastaw, hipoteka, przedmiot zakładu, zakładnik, rękojmia, znak, dowód, dowody wzajemnej miłości, dzieci, skarby, syn, córka, bliscy, drodzy, krewni, rodzina, miłość do osób bliskich’. Por. Słownik łacińsko-polski, t. 4, red. M. Plezia, Warszawa 1999, s. 162. 
jawiło się dzieło, w którym odnajdujemy tę samą silną świadomość matczynych obowiązków. Co więcej, pismo to dostarcza nam wielu dodatkowych i cennych informacji na temat statusu i zadań arystokratek, które zostawały matkami. 30 listopada 841 roku w mieście Uzès ${ }^{20}$, stanowiącym ówczesna stolicę Marchii Hiszpańskiej, frankońska markiza Dhuoda z Septymanii rozpoczęa pisanie swojego dydaktycznego traktatu ${ }^{21}$. Jej dzieło przeszło do historii jako Liber manualis - Podręcznik. Stanowi ono zupełnie odosobniony przykład kobiecej twórczości, która objawiła się na łonie zdecydowanie męskiej kultury karolińskiej. Dhuoda więc, tak jak dwa wieki wcześniej Herchenefreda, pełni rolę swoistego rodzaju kamienia milowego, który daje historykom szansę na postawienie wielu pytań badawczych z zakresu historii kobiet, ich wykształcenia oraz społecznych ról.

Bez odpowiedzi pozostaje jednak pytanie, czy karolińska arystokratka znała i czy być może mogła być zainspirowana listami swojej poprzedniczki. Jest to w pewien sposób prawdopodobne, biorąc pod uwagę fakt, że pod koniec VIII wieku w imperium karolińskim powstał oraz został spopularyzowany życiorys Dezyderiusza (Vita Desiderii), adresata korespondencji Herchenefredy. Do wspomnianej hagiografii biskupa Cahors zostały wówczas włączone trzy listy, które otrzymał on od matki i przechowywał aż do swojej śmierci.

Choć Dhuoda nie przywołała w Liber manualis imienia Herchenefredy, to jednak w wielu miejscach sięgnęła po retorykę oraz zagadnienia tożsame z tymi, które odnajdujemy w listach do Dezyderiusza. Markiza Septymanii pragnęła skomponować uniwersalny podręcznik dla swojego pierworod-

20 Miasto Uzès było rodzinną posiadłością męża Dhuody Bernarda. Leżało w rejonie Septymanii, która stanowiła graniczną krainę z Emiratem Kordoby. Pobyt Dhuody w Uzès przebiegał pod znakiem permanentnej samotności. Markiza zarządzała lennami męża, podczas gdy on realizował swą karierę urzędniczą na cesarskim dworze. Arystokratka samodzielnie wychowywała też starszego syna Wilhelma do ukończenia przezeń 16 roku życia.

21 Informacje te poznajemy $\mathrm{z}$ rozdziałów Liber manualis. Łaciński tekst cytuję za: Dhuoda, Liber manualis Dhuodane quem ad filium suum transmisit Wilhelmum, w: Manuel pour mon fils, red. P. Riché, tł. B. De Vregille - C. Mondésert, SCh 225, Paryż 1997. Por. Liber manualis 11, 2, SCh 225, 368-370: „+ Incoatio huius libelli II anno obitus Ludouici condam imperatori, II $^{\circ}$ kalendas decembri, sancti Andreae missa, incoante sanctum Domini Aduentum. Finitus est autem, auxiliante Deo, IIII $^{\circ}$ nonas februarii, Purificationis sanctae et gloriosae semperque uirginis Mariae, [...]" - 'Początek tej książeczki sporządziłam w drugim roku po śmierci cesarza Ludwika, dwa dni przed kalendami grudnia [30 listopada 841 rok], w dniu wspomnienia świętego Andrzeja, na początku świętego adwentu Pana. Została zaś ona ukończona z Bożą pomocą na cztery dni przed nonami lutego [2 lutego 843 rok], w święto oczyszczenia Najświętszej Marii Panny' (tł. fragmentów Liber manualis - M. Chudzikowska-Wołoszyn). 
nego, szesnastoletniego syna Wilhelma. Jej celem było zredagowanie księgi zawierającej listę matczynych rad, które służyć miały przede wszystkim edukacji duchowej i moralnej młodego arystokraty. Bezpośrednim impulsem do napisania traktatu była samotność, ogromna tęsknota oraz świadomość nieuchronnej śmierci, którą odczuwała karolińska autorka ${ }^{22}$. Szesnastoletni wówczas Wilhelm przebywał, z woli ojca - wpływowego możnego Bernarda z Septymanii $(\uparrow 844)^{23}-\mathrm{w}$ centrum politycznego konfliktu, który wybuchł pomiędzy synami Ludwika Pobożnego (778-840).

22 Por. Liber manualis, Praefatio, SCh 225, s. 86: „Sed cum diu, ob absentiam praesentiae vestrae, sub iussione senioris mei, in praedicta, cum agone illius iam gaudens, residerem urbe, ex desiderio utrorumque vestrum hunc codicillum secundum paruitatis meae intelligentiam tibi transcribi et dirigere curaui' - 'Lecz gdy, z rozkazu mojego pana, we wspomnianym mieście pozostaję już dość długo pozbawiona waszej bliskości, ciesząc się jego sukcesami, postarałam się, z powodu tęsknoty za tobą i za każdym z was, spisać i przekazać tobie tę książeczkę na miarę małości mego rozumu'. Liber manualis, In nomine Sanctae Trinitatis, SCh 225, s. 72: ,[...] et me Dhuodanam, o fili Wilhelme, a te elongatam conspiciens procul, ob id quasi anxia et utilitatis desiderio plena, [...]” '[...] ja Dhuoda, mój synu Wilhelmie, żyjąc już tak długo w oddali od ciebie i poprzez to będąc przepełnioną zmartwieniem i pragnieniem bycia przydatną, [...]'. Liber manualis 10, 1, SCh 225, s. 338: „Sed quia tempus resolutionis non tardat me meum, et aegritudo angustiarum corpus undique conterit istum tibi et fratri ut prosit, quod collegi festinans" 'Jednak ponieważ czas mego pożegnania nie opóźnia się, a choroba i niedostatek dręczą ze wszystkich stron (me) ciało, ta (książeczka) tobie i bratu, aby była przydatna, którą zebrałam, spiesząc się'.

23 Bernard z Septymanii z uwagi na bliskie pokrewieństwo z królewskim rodem Pepinidów szybko zbliżył się do cesarskiego dworu Ludwika Pobożnego. W 826 roku odniósł zwycięstwo w starciu z muzułmańskimi wojskami, które zajęły Barcelonę. Sukces ów jeszcze bardziej wzmocnił jego pozycję, zapewnił dobra ziemskie w pasie Marchii Hiszpańskiej oraz lukratywny urząd cesarskiego szambelana. Bernard na stałe związał się z Akwizgranem, odsyłając świeżo poślubioną małżonkę Dhuodę do miasta Uzès w Septymanii, które było siedzibą jego rozległych dóbr. Bernard okazał się jednak nielojalnym sługą swojego seniora Ludwika. Stał się znienawidzonym członkiem dworu przede wszystkim ze względu na swój hańbiący romans z cesarzową Judytą. Wkrótce później odstąpił od cesarza i podżegał zwaśnione stronnictwa do wojny domowej. W konflikcie, który rozgorzał pomiędzy synami karolińskiego imperatora, stanął po stronie Pepina II Akwitańskiego (823-864). Niestety, rozstrzygająca bratobójczy spór bitwa pod Fontenayen-Puisaye (25 VI 841) nie przyniosła dlań korzystnego rozwiązania. Karol Łysy (823877) oraz Ludwik Niemiecki (806-876), którzy wyszli zwycięsko ze starcia, okazali się być nieprzejednani wobec zdrady Bernarda. On sam, aby móc zyskać dla siebie wolność, powierzył władcom własnego syna Wilhelma jako wasala i zakładnika. W tym czasie powrócił do Uzès i zabrał Dhuodzie drugiego z synów, trzymiesięcznego Bernarda. Wraz z niemowlęciem oraz grupą oddanych sobie towarzyszy zbiegł do Akwitanii, którą nadal władał sprzymierzony z nim Pepin Akwitański. 
Po bratobójczej walce pod Fontenay-en-Puisaye (841) został przekazany w akcie komendacji zwycięskiemu królowi-Karolowi Łysemu (823-877) ${ }^{24}$. Los Wilhelma pozostawał niepewny, podobnie jak przyszłość jego matki, która samotnie zarządzała majątkiem tracącego pozycję i honor Bernarda. Okazuje się jednak, że mniej więcej w tym samym czasie Dhuoda została pozbawiona kontaktu nie tylko z pierworodnym Wilhelmem. Jej małżonek, tuż po niekorzystnym dla siebie militarnym sukcesie Karola Łysego, zdecydował się zabrać z Uzès także młodszego z synów, trzymiesięcznego Bernarda ${ }^{25}$, którego imienia Dhuoda nie poznała niestety aż do swojej śmierci. Zmarła tuż po skończeniu dzieła, czyli jeszcze w 843 roku.

Rozłąka z ukochanymi synami, ale także niepokój o ich przyszłość stały się asumptem do napisania obszernego pisma. Jego znakiem rozpoznawczym są te same silne matczyne emocje, które już wcześniej dały o sobie znać w listach Herchenefredy. Pisma obu autorek z całą pewnością zasadniczo różnią się od siebie pod względem objętościowym. Razem wzięte trzy listy Herchenefredy mogłyby stanowić zaledwie jeden z jedenastu rozdziałów traktatu Dhuody. Mimo wszystko jednak pomiędzy dziełami odnajdujemy wiele znaczących punktów stycznych. Zbliżają się one do siebie przede wszystkim z uwagi na swą emocjonalną wymowę. Narracyjne dzieło markizy Septymanii łączy w sobie elementy pamiętnika, listu oraz testamentu i stąd, w swym osobistym wydźwięku, zbliża się do prywatnej korespondencji Herchenefredy. Istotne jest, że Dhuoda realizowała te same instrukcje, które dwa wieki wcześniej pojawiły się w listach do biskupa Cahors. Znacznie je jednak rozszerzyła i rozbudowała w bardziej drobiazgowe treści. Do swoich licznych wychowawczych wskazówek wprowadziła bogaty materiał egzemplifikacyjny, który pochodził z ksiąg Pisma Świętego oraz dzieł Ojców Kościoła (Augustyna, Grzegorza Wielkiego, Hieronima oraz Izydora z Sewilli). Nie należy zapominać, że Wilhelm był znacznie młodszy od Dezyderiusza i właśnie z myślą o nim, dopiero wstępującym w dorosłość arystokracie, Dhuoda zredagowała niezwykle obrazowy przewodnik. Księga ta miała w głównej mierze sprawić, ażeby życie Wilhelma zawsze podobało się Bogu i stało się dla niego przepustką do życia wiecznego. Drugoplanowym zamiarem matki było zaznaczenie swojej trwałej obecności w życiu pierworodnego syna. Odwołując się do autorytetu matki i wychowawczyni, Dhuoda odnalazła w sobie siłę, aby

24 Por. Liber manualis, Praefatio, SCh 225, s. 86: „Audivi enim quod genitor tuus Bernardus in manus domni te commendavit Karoli regis; admoneo te ut huius negotii dignitatem usque ad perfectum voluntati operam des" - 'Usłyszałam bowiem, że twój ojciec Bernard oddał cię w ręce króla Karola. Napominam cię, abyś oddał się poważaniu tej sprawy całą [twoją] wolą'.

25 Młodszy syn Dhuody przeszedł do historii jako Bernard Kosmata Stopa (841-886). 
stanąć w szranki z jedynie męskimi wówczas twórcami literatury. Udało się jej spisać obszerną dydaktyczną księgę, której ponadczasowa wymowa tkwi, tak jak w przypadku listów Herchenefredy, w silnej oraz instynktownej matczynej miłości.

Liber manualis zaliczany jest do popularnego w dobie karolińskiej nurtu piśmiennictwa napominającego i wzorcotwórczego. Tego rodzaju dzieła określone zostały w historii literatury mianem zwierciadeł (specula). Osoba adresata oraz skomponowany dla niej program wychowawczy determinowały przynależność do zwierciadeł królewskich albo świeckich. Podręcznik Dhuody reprezentuje tzw. zwierciadło laickie, czyli speculum laicalis. Pisma Herchenefredy, co zostało już odnotowane, wraz z innymi merowińskimi i wczesno-karolińskimi listami napominającymi (litterae exhortatoriae) stanowią ważne i niezbędne preludium, które przyczyniło się do rozwinięcia i ukonstytuowania pełnej formuły zwierciadeł.

Niestety, niewiele wiemy na temat pochodzenia samej Dhuody. W Podreczniku spisanym dla Wilhelma koncentruje się ona przede wszystkim na rodzinie Bernarda, milczy natomiast na temat własnych przodków i krewnych ${ }^{26}$. Źródłem informacji dotyczących wykształcenia markizy może stać się oczywiście analiza samego traktatu. Rozpoznajemy, że arystokratka posługiwała się ponadprzeciętną znajomością łaciny. Nie do końca była to jednak bezbłędna i czysta składniowo łacina scholarska. Dhuoda korzystała raczej ze zbarbaryzowanej odmiany łaciny ludowej, na bazie której była jednak w stanie konstruować nawet te bardziej skomplikowane rozważania natury teologicznej. Jej formacja intelektualna $\mathrm{z}$ pewno-

26 Edouard Bondurand odnotował, że Dhuoda mogła być arystokratką wywodzącą się z Septymanii, prawdopodobnie o wizygockim pochodzeniu. Por. E. Bondurand, L'education carolingienne: Le Manuel de Dhuoda, Paris 1887, s. 16-17. Zdaniem Joachima Wollascha imię Dhuoda miało pochodzenie germańskie. Por. J. Wollasch, Eine adlige Familie des früher Mittelalters. Ihr Selbstverständnis und ihre Wirklichkeit, „Archiv für Kulturgeschichte” 39 (1957) s. 184-185. Spotykane było w północnej Francji w formach Duda, Tota, Thuada i Doda. Ostatnią z wersji imienia (Doda), jak podają roczniki z 853 roku, nosiła konkubina Lotara, syna Ludwika Pobożnego. Por. E. Salin, La civilization mérovingienne, d'après les sépultures, les textes et le laboratoire, t. 2, Paris 1952, s. 86-87. Max Manitius postawił natomiast hipotezę, że Dhuoda prawdopodobnie była córką zamożnego arystokraty z Nimes (miasto w rejonie Septymanii) o imieniu Dadil, który w swoim testamencie z 813 roku wymienił zmarłą córkę o imieniu Dadana. Por. M. Manitius, Geschichte der Lateinischen Literatur des Mittelalters, t. 1, München 1959, s. 442. Za pochodzeniem arystokratki z regionu Nimes optował także Franz Brunhölzl. Zob. F. Brunhölzl, Geschichte der lateinischen Literatur des Mittelalters, t. 1, Munich 1975, s. 409. Ronald Malan założył z kolei, że korzenie Dhuody mogą sięgać nawet Gaskonii. Zob. R. Malan, The Ancestry of Dhuoda, Duchess of Septimania, „The Genealogist” 11/1 (1997) s. 116. 
ścią wykraczała poza typową domową edukację, którą możni zapewniali swoim dzieciom. Erudycja Dhuody potwierdza, iż być może kształcona była ona pod okiem jakiegoś duchownego i dzięki niemu korzystała także z zasobów dość dobrze wyposażonej biblioteki. Liczne zapożyczenia z tradycji monastycznej oraz patrystycznej świadczą o jej oczytaniu, a także pragnieniu zdobywania wiedzy. Jest wielce prawdopodobne, że posiadała swój własny księgozbiór. W kilku miejscach pisma dowodziła, jaką wartość miały dla niej księgi ${ }^{27}$.

\section{Status, kompetencje oraz zadania arystokratek frankońskich}

Ze względu na niewystarczającą ilość przekazów źródłowych właściwie niemożliwe staje się ukonstytuowanie pewnego osądu na temat dostępności, poziomu i efektywności edukacji świeckich kobiet, które żyły tak w dobie merowińskiej, jak i karolińskiej. Zachowane świadectwo Herchenefredy i Dhuody rzuca jednak pewne światło na kwestię erudycji możnych kobiet. Uczoność obu arystokratek pozwala wnioskować, że na możnowładczych dworach kultura nie stanowiła wcale okazjonalnego czy też sporadycznego zjawiska. Dostęp do starannego wykształcenia miały więc również kobiety. Oczywiście ich zasób wiedzy mógł być najróżniejszy. Zależny zapewne od lokalnych tradycji, osobistych upodobań, zainteresowań i wreszcie także dostępu do dobrego nauczyciela ${ }^{28}$.

Analiza Liber manualis dowodzi, że Dhuoda (analogicznie do Herchenefredy) była w pełni świadoma pozycji, którą pełniła w swojej wspólnocie społecznej oraz rodzinnej. Rola kobiety sytuowała ją oczywiście jedynie na marginesie społeczeństwa. Była całkowicie podporządkowana i zależna od męskiego świata. Doskonale znała i akceptowała ten porządek, który od stuleci obowiązywał w jej germańskim rodzie. W słowach, które kierowała do pierworodnego syna, wielokrotnie dawała wyraz swojej podrzędności. Bez sprzeciwu akceptowała fakt, że nie jest w stanie dorównać mężczyznom w zakresie kompetencji erudycyjnych czy też pisarskich. Często nazywała siebie niegodną, ułomną, pozbawioną zdolności pojmowania oraz słabą ${ }^{29}$.

27 Por. Liber manualis, Prologus, SCh 225, s. 80; 1, 7, SCh 225, s. 114.

28 Por. E. Auerbach, Język literacki i jego odbiorcy w późnym antyku łacińskim i średniowieczu, tł. R. Urbański, Kraków 2006, s. 237.

29 Por. Liber manualis, Incipit prologus, SCh 225, s. 80: „Multis plura patent, mihi tamen latent, meae quoque similes, obscurato sensu, carent intellectu, si minus dicam, plus 
W Podręczniku nakreśliła wyraźną hierarchię doczesnych dostojeństw. Podkreślała, że cześć należna ojcu jest najważniejszym z obowiązków spoczywających na jego spadkobiercach. Wilhelm powinien jej zdaniem zaraz po Bogu niezłomnie miłować ojca, być mu wiernym i z należytą bojaźnią akceptować jego decyzje:

Nie mam żadnych oporów, aby oznajmić ci, tak jak tylko to potrafię, że powinieneś odczuwać bojaźń, kochać, doradzać, a także być wiernym we wszystkim twojemu panu i ojcu Bernardowi $[\ldots]^{30}$. Napominam więc ciebie, mój najukochańszy synu Wilhelmie, abyś w pierwszej kolejności kochał Boga, tak jak wyżej masz to odnotowane, następnie kochaj, okazuj bojaźń i czcij ojca twego: uświadom sobie, iż od niego wzięła początek twoja pozycja na tym świecie. Powinieneś o tym wiedzieć, ponieważ tak jest już od najdawniejszych czasów, że ci, którzy wielbili ojców i tym szczerze byli oddani, oni właśnie zasłużyli, ażeby odebrać błogosławieństwo od Boga $[\ldots]^{31}$. Najpierw z całego

ego" - "Te liczne sprawy, które są oczywiste dla wielu ludzi, dla mnie wciąż pozostają nieodkryte, także i dla tych, którzy są podobni do mnie, pozbawieni zdolności pojmowania, o zaciemnionym rozeznaniu, ja jednak jestem bardziej [niż oni], o ileż [mi jednak] za mało, abym mogła o tym powiedzieć'. Liber manualis, Incipit prologus, SCh 225, s. 80: „Dhuoda quanquam in fragili sensu, inter dignas uiuens indigne, [...]” - 'Ja, Dhuoda, chociaż jestem słabego umysłu i żyję niegodnie pośród godnych [niewiast]'. Liber manualis, Praefatio, SCh 225, s. 86: ,[...] hunc codicillum secundum paruitatis meae intelligentiam tibi transcribi et dirigere curaui" - '[...] postarałam się spisać i przekazać tobie tę książeczkę na miarę małości mego rozumu’. Liber manualis 1, 1, SCh 225, s. 96: „,...] considerans casum humanae fragilitatis meae, me reprehendi indesinenter non cesso, cum sim misera, cinisque et puluis $[\mathrm{Rdz} 18,27]$. [...] exigua et infimi generis orta" - 'Znając moją ludzką słabość, nigdy nie zaprzestaję siebie karać, podczas gdy jestem nieszczęśliwa, a także jestem pyłem i prochem. [...] tak mało znacząca i zrodzona w tak niskim gatunku'. Liber manualis 1, 4, SCh 225, s. 104: „Adhuc, quanquam fragilis ad umbram, [...]' - 'I chociaż ciągle słaba jestem niczym cień [...]'. Liber manualis 1, 6, SCh 225, s. 110: „Et quid, situla fragilis, dicam?” - 'Ja, która jestem krucha niczym dzban, cóż mogłabym powiedzieć?'. Liber manualis 2, 3, SCh 225, s. 126: „Ego autem Dhuoda tepida et desidiosa fragilisque et declinans semper ad ima, [...]" - 'Ja natomiast Dhuoda jestem słaba, bezczynna i krucha, zawsze też zwracam się ku głębinom'. Liber manualis 3, 5, SCh 225, s. 158: „Quid dicam de te, fili, quanquam indigna infelixque atque exigua Dhuoda?" - 'Cóż miałabym powiedzieć o tobie, synu, ja Dhuoda, która jestem niegodna, nieszczęśliwa i mało znacząca?’.

30 Liber manualis 3, 1, SCh 225, s. 134: „Qualiter domno et genitori tuo Bernardo, tam praesens quam absens, timere, amare, atque fidelis in omnibus esse debeas, insinuare, ut valeo, non pigeo".

31 Liber manualis 3, 2, SCh 225, s. 140-142: „Ego autem admoneo te, desiderantissime fili Wilhelme, ut in primis diligas Deum sicut supra habes conscriptum; deinde ama, 
serca i umysłu miłuj i lękaj się Pana Boga, wszystkimi otwartymi siłami, potem [miłuj] ojca twego we wszystkim [w szczęściu i niepowodzeniu] ${ }^{32}$.

Jedynie przy wsparciu ojcowskiej siły i znaczenia jego znakomitego rodu można było, jak wskazywała dalej, dotrzeć do urzędów i godności. Dhuoda nie kryła swojej dumy z przynależności do tzw. kasty wybranych, ludzi dobrze urodzonych, którzy byli potężni i skuteczni. To poczucie wartości starała się przekazać także Wilhelmowi. Jednak nie tylko z myślą o nim propagowała potęgę rodu swojego męża i synów. Jej celem było stworzenie dzieła, które z rąk Wilhelma trafiłoby także do innych możnych. Wiedziona tą myślą nie ustawała, aby wielokrotnie przypominać o w pełni należnym jej synom szlachectwie i społecznej randze. Przykładem mogą być jej słowa, które zamknęła w trzeciej księdze Podręcznika: „Trwa pewna stała i niezmienna prawda - nikt nie może dostąpić godności, o ile nie pochodzi od szlachetnego ojca, bez którego także nie zdoła dotrzeć do innej, bardzo ważnej osoby na wysokości władzy"33.

Karolińska arystokratka z dumą wymieniała chlubnych protoplastów akwitańskiego rodu Bernarda. Wilhelm odziedziczył swą szlachetną krew po pradziadach wywodzących się $\mathrm{z}$ austrazyjskiego rodu Pepinidów ${ }^{34}$. Matka instruowała syna, aby pamiętał o cyklicznych modlitwach za zmarłych przodków Bernarda, dzięki którym stał się dziedzicem ich szlachetnej krwi, a także mienia ${ }^{35}$. Przypominała również, iż do obowiązków Wilhelma

time, et dilige patrem tuum; scitoque, ex illo tuus in saeculo processit status. Scias enim quia ab antiquis temporibus qui dilexerunt patres et illis veraciter obedientes fuerunt, benedictionem a Deo ab illis accipere meruerunt".

32 Liber manualis 10, 2, SCh 225, s. 342: „In primis Dominum Deum ex toto corde et mente, totis viribus pansis, time et dirige, genitorem tuum inde per cuncta”.

33 Liber manualis 3, 2, SCh 225, s. 140: „Certa quidem et fixa manet conditio, quod nullus nisi ex genitore procedat, non potest ad aliam et summam personam culmine pervenire senioratus".

34 Szesnastoletni Wilhelm imię otrzymał po swym dziadku z linii ojca Wilhelmie z Akwitanii (zm. 812) zwanym również Świętym lub Wilhelmem z Gellony. Pod koniec życia pełnił posługę brata świeckiego w klasztorze w Gellone. Wilhelm z Akwitanii był synem Thierrego IV (Theoderic IV, zm. ok. 782) oraz Aldany, córki frankońskiego majordoma Karola Młota (686-741).

35 Por. Liber manualis 8, 14, SCh 225, s. 318: „Ora pro parentibus genitoris tui, qui illi res suas in legitima dimiserunt hereditate" - 'Módl się za przodków twojego ojca, którzy jemu zostawili swoje mienie w zgodnym z prawem spadku'. Liber manualis $10,5, \mathrm{SCh}$ 225, s. 354: „Quos de quosdam praedictis supra praetermisi personis, his breviatos agnosce. Id sunt: Wilhelmus, Chungundis, Gariberga, Vuithburgis, Teddericus, Gothzelmus, Guarnarius, Rothlindis" - 'Te imiona, które pominęłam powyżej pośród wspomnianych, poznaj w skrócie. Oto są Wilhelm [Wilhelm z Gellony, ojciec Bernarda], Kunegunda 
należy uzupełnianie rodzinnej księgi wypominkowej, za pośrednictwem której kolejne pokolenia zachować będą mogły pamięć o zmarłych antecesorach. W Liber manualis czytamy:

Ktokolwiek z twojego rodu schodził będzie ze świata, co jest w mocy nie kogoś innego jak tylko Boga, i kiedy on sam to postanowi, podobnie jak to było z panem Heribertem [brat Bernarda z Septymanii], wujem twoim, proszę cię, o ile będziesz wówczas żył, poleć, ażeby imię jego dopisać do imion wymienionych już wcześniej, proszę także o modły za niego ${ }^{36}$.

Siła rodu męża miała dla Dhuody znaczenie zdecydowanie pierwszoplanowe. Podrzędność względem małżonka nie wymagała jednak od niej tłumienia poczucia posiadania własnej, równie szlacheckiej krwi. Karolińska arystokratka zdawała sobie sprawę, jak ważną rolę odgrywa ona w wywyższeniu rodu Bernarda. Małżeństwo, które zawarła z potomkiem Wilhelmidów, było tzw. „korzystną transakcją”, która pomnażała wpływy obu rodów. Dzięki swojej arystokratycznej proweniencji była w stanie obdarzyć Bernarda prawowitymi spadkobiercami o znakomitej i niezepsutej $\mathrm{krwi}^{37}$. Znaczenie swojego honorowego szlachectwa podkreśliła następującymi słowami: „Wszystko w nas jest zapisane w kalendach [danych] miesięcy ${ }^{38}$, mianowicie i data, w której ja dołączyłam do twojego

[pierwsza małżonka Wilhelma z Gellony], Gerberga [siostra Bernarda, zakonnica, która zginęła w 834 roku zamknięta w beczce i wrzucona do Saony, stała się ofiarą politycznych błędów brata], Guitberga z Hornbach [druga żona Wilhelma z Gellony], Thierry [najstarszy syn Wilhelma z Gellony, brat Bernarda z Septymanii, ojciec chrzestny Wilhelma], Gocelm [brat Bernarda z Septymanii], Guarnarius, Rotlinda [ostatnie dwa imiona nie zostały jednoznacznie zidentyfikowane, być może byli to dalecy krewni Bernarda]'.

36 Liber manualis 10, 5, SCh 225, s. 354: „Quisquis de tua migraverit stirpe, quod non est aliud nisi in potestate Dei, quando iusserit ipse, similiter et de domno Ariberto avunculo tuo, rogo, tu si superstes fueris, nomen illius cum praescriptis personis supra iube transcribi, orando illum".

37 Należy wziąć pod uwagę fakt, że w epoce karolińskiej wierzono w istnienie tzw. spermy kobiecej, która w równym stopniu z nasieniem męskim miała wpływać na akt poczęcia. Skutkiem stosunku seksualnego było także, jak zakładano, nierozłączne zmieszanie obu krwi. Szlachectwo obu rodziców było więc czynnikiem niezbędnym dla zachowania jakości krwi i przekazania jej bez ryzyka zwyrodnienia. Por. G. Duby, Rycerz, kobieta i ksiądz. Matżeństwo w feudalnej Francji, tł. H. Geremek, Warszawa 1986, s. 40-41.

38 Dhuoda nawiązuje tutaj do daty swojego ślubu z Bernardem i narodzin Wilhelma. Oba wydarzenia związane były z pokrewnym terminem kalend. Ślub Dhuody z Bernardem odbył się trzy dni przed kalendami lipcowymi. Wilhelm zaś przyszedł na świat trzy dni przed kalendami grudniowymi. Por. Liber manualis, Praefatio, SCh 225, s. 84: „Anno feliciter propitio, XI, domno nostro Ludouico condam fulgente in imperio, concurrente V, 
ojca, albo także i ta, w której z nas obojga początek wzięła twoja pozycja na tym świecie" 39 .

Matka wielokrotnie zwracała się do Wilhelma, akcentując jego nieskalaną i honorową krew. Nazywała go „szlachetnym synem” oraz „,chłopcem” (nobilis natus $^{40}$, nobilis puer ${ }^{41}$ ), przydawała mu także określenie optimus ${ }^{42}$, które zarezerwowane było dla klasy wybranych, czyli najdostojniejszych. Przemawiając do syna, sięgała również po patetyczne apostrofy. Przykładem może być choćby jej przemowa do szlachetnej młodości Wilhelma - tuam iuventutis nobilitatem, którą znajdujemy już na początku pierwszej księgi Podręcznika ${ }^{43}$. Liber manualis wypełniony został matczyną czułością, która już wcześniej stała się znakiem rozpoznawczym listów Herchenefredy. Szesnastoletni Wilhelm, jak czytamy, był najbardziej upragnionym synem (desiderantissimus filius) ${ }^{44}$ mar-

III Kalendarum iulii diem, in Aquisgrani palatio, ad meum dominum tuumque genitorem Bernardum legalis in coniugio accessi uxor. Et iterum in tertio decimo anno regni eius, III Kalendarum decembrium, auxiliante, ut credo, Deo, tua ex me, desiderantissime fili primogenite, in saeculo processit natiuitas" - 'W jedenastym roku cesarskich rządów naszego pana Ludwika, panującego szczęśliwie z miłosiernym Chrystusem i już pogrzebanego, w roku piątej konkurenty, trzy dni przed kalendami lipcowymi [29 VI 824] w pałacu w Akwizgranie zostałam oddana w małżeństwo jako prawowita żona memu panu i twojemu ojcu Bernardowi. Jeszcze w trzynastym roku jego [Ludwika Pobożnego] panowania, trzy dni przed kalendami grudnia [29 XI 826], z Bożą pomocą, jak wierzę, miało miejsce twoje, z mojego ciała, przyjście na świat, mój najbardziej upragniony pierworodny synu'.

39 Liber manualis 10, 1, SCh 225, s. 340: „Tempus namque ex quo ad genitorem tuum perueni, vel tuus ex nobis in saeculo processit status; Kalendis mensarum, cuncta feruntur in nobis".

40 Por. Liber manualis 10, 2, SCh 225, s. 344: „En, ut curas habeas, nobilis nate, [...]" - 'Tak więc skrzętnie poszukuj, szlachetnie urodzony synu'.

41 Por. Liber manualis 4, 7, SCh 225, s. 230: „Quod absit a te, nobilis puer” - 'Oby to się tobie nie zdarzyło, szlachetny chłopcze'. Liber manualis 9, 5, SCh 225, s. 334: ,[...] nobilis puer, adsisto in cunctis" - 'Szlachetny chłopcze, ja jestem przy tobie we wszystkich sprawach'. Liber manualis 10, 4, SCh 225, s. 350: ,[...] nullum similem tui superstitem relinquo, $[\ldots]$ nobilis puer" - 'Szlachetny chłopcze $[\ldots]$, nie pozostawiam nikogo podobnego do ciebie'. Liber manualis 11, 2, SCh 225, s. 368: „Vale et uige, nobilis puer, semper in Christo" - 'Bądź silny i zdrów, szlachetny chłopcze, zawsze w Chrystusie'.

42 Por. Liber manualis 3, 7, SCh 225, s. 164: „Quod tunc in illis, ita oro ut et nunc, cotidie, semper in te crescat, obtime fili" - 'Modlę się, aby [taka rada, jak była w tych ludziach] teraz wzrastała w was, każdego dnia i zawsze, najdostojniejszy mój synu”.

43 Por. Liber manualis 1, 1, SCh 225, s. 96: „Rogo et humiliter suggero tuam iuventutis nobilitatem, [...]" - 'Proszę i pokornie podpowiadam twojej szlachetnej młodości, $[\ldots]$ '.

44 Por. Liber manualis, Praefatio, SCh 225, s. 84: „[...] desiderantissime fili primogenite”. Liber manualis 3, 2, SCh 225, s. 140: „[...] desiderantissime fili Wilhelme”. 
kizy, która z pełną otwartością nazywała go także „najukochańszym” (amantissimus $^{45}$ oraz ,pięknym” (pulcher) ${ }^{46}$.

Obok wszechobecnego toposu skromności, który autorka budowała w odniesieniu do swoich stricte kobiecych kompetencji, w Podręczniku dostrzegamy także tak istotny oraz wyraźnie przybierający na sile wychowawczy ton i autorytet matki. Dhuoda pozwala nam dostrzec swoją świadomość społecznych oczekiwań względem zajmowanej przez nią rangi i pozycji. Była chrześcijańską arystokratką, która wydała na świat szlachetnego potomka. Jej naturalnym obowiązkiem stawało się więc zapewnienie mu opiekuńczo-wychowawczej pieczy, której sedno tkwiło w chrześcijańskiej moralności. Już we wstępie do Liber manualis matka Wilhelma zademonstrowała silną potrzebę zrealizowania swojego pedagogicznego zadania. Oczekiwano od niej udzielania instrukcji swoim dzieciom, a także dawania im odpowiednich przykładów ${ }^{47}$. Niestety, rozłąka z synami nie ułatwiała wypełnienia przypisanej jej macierzyńskiej misji, o której pisała w następujący sposób:

Zdaję sobie sprawę, że większość [kobiet] raduje się, że jest na tym świecie ze swoimi dziećmi, ale ja, Dhuoda, o mój synu Wilhelmie, jestem od ciebie tak daleko i z tego powodu jestem przygnębiona i przepełniona pragnieniem bycia przydatna dla ciebie. To dziełko więc posyłam napisane w moim imieniu, tak jak zwierciadło, abyś je czytał, niczym wzór dla ciebie. Cieszę się, że nawet wtedy, gdy ja jestem oddalona swym ciałem od ciebie, ta książeczka jest obecna i kiedy ją czytasz, ona przypomina ci, co powinieneś ze względu na mnie robić $^{48}$.

Widzimy więc, że rozdzielenie Dhuody z synem w żaden sposób nie oznaczało dla niej usprawiedliwionego odstąpienia od wypełniania wychowawczych obowiązków. Pragnienie ,bycia przydatną" dla Wilhelma okazało się uczuciem dominującym. Wilhelm wkraczał w dorosłość, znalazł

45 Por. Liber manualis 1, 5, SCh 225, s. 108: „[...] o amantissime fili Wilhelme”.

46 Por. Liber manualis 1, 2, SCh 225, s. 100: ,[...] o pulcher fili Wilhelme”. Liber manualis 1, 7, SCh 225, s. 114: ,[...] o mi fili Wilhelme pulchre et amabilis”.

47 Por. V.L. Garver, Women and Aristocratic Culture in the Carolingian World, Ithaca - London 2009, s. 122.

48 Liber manualis, In nomine Sanctae Trinitatis, SCh 225, s. 72: „Cernens plurimas cum suis in saeculo gaudere proles, et me Dhuodanam, o fili Wilhelme, a te elongatam conspiciens procul, ob id quasi anxia et utilitatis desiderio plena, hoc opusculum ex nomine meo scriptum in tuam specietenus formam legendi dirigo, gaudens quod, si absens sum corpore, iste praesens libellus tibi ad mentem reducat quid erga me, cum legeris, debeas agere". 
się nagle w pełnym konfliktów męskim świecie i, co do czego była przekonana Dhuoda, potrzebował podpowiedzi, upomnień i kontroli. Matczyna opieka, w rozumieniu karolińskiej uczonej, miała dopomóc i dopełnić wykształcenie swoistego rodzaju arystokratycznej kultury, która opierałaby się na prawości, miłosierdziu i szczodrości. Matka czuła się odpowiedzialna za przygotowanie Wilhelma do właściwego wypełniania przypisanej mu z racji urodzenia społecznej funkcji. Status i pozycja, którą posiadał, nie były bowiem wartością samą w sobie, ale misją i zobowiązaniem. Arystokracja wywierała realny wpływ na budowanie społecznego ładu. Dhuoda pragnęła, aby jej pierworodny syn z prawdziwym oddaniem służył swojej chrześcijańskiej wspólnocie. Tylko w ten sposób mógł on osiągnąć doczesne szczęście, a także zbawienie. Wierzyła, że Wilhelm jest w stanie zrealizować ów cel poprzez praktykowanie niezbędnych cnót. Co więcej, $\mathrm{w}$ jej opinii to właśnie ona, tak jak nikt inny, posiadała wszelkie niezbędne predyspozycje, aby tę wiedzę najskuteczniej mu przekazać.

Dhuoda pragnęła przybliżyć Wilhelmowi chrześcijańska istotę szlachectwa, dziedziczoną poprzez nieskalaną krew, godność, która w naturalny sposób zobowiązywała do skutecznego i znamienitego działania. Chcąc nakłonić syna do przemyśleń wokół wymiaru i rangi posiadanego przez niego szlachectwa, moralizatorsko pytała i pouczała:

Jakaż korzyść, mój synu, ze szlacheckiej krwi, jeżeli ciało jego zdeprawowane jest przez niesprawiedliwość, i zstępuje w zepsucie, aby płakać na zawsze? Żadnej nie ma korzyści dla siebie, jeśli cały świat zyskuje, a samego siebie traci (Mk 8,36). Albowiem świat i pożądliwość jego przemija (1J 2,17). I chociaż człowiek zabłyśnie złotem, perłami i purpurą, to podąży ku podziemiom jako marny i nagi, niczego nie zabierając ze sobą, chyba, że żył dobrze, pobożnie, czysto i w godny sposób ${ }^{49}$.

\section{Wychowawcza misja matek}

Szczegółowa analiza listów Herchenefredy, a także zwierciadła Dhuody z Septymanii, pozwala nam zbudować przekonanie, iż obie frankońskie

49 Liber manualis 4, 8, SCh 225, s. 248: „Quae utilitas, fili, in sanguine nobili, si propter iniustitias corpus corrumpatur suum, descendens ad corruptionem ut lugeat semper? Nichil enim illi proficit, si totum lucretur mundum et se perdat. Nam «et mundus transit, et concupiscientia eius». Et licet homo auro, gemisque et purpura nitescat, uilis et nudus ibit ad umbras, nichil tollens secum, nisi quod bene, quod pie, quod caste, quod digne uixerit ipse". 
arystokratki podjęły się odważnego pisarskiego zadania tylko z uwagi na pragnienie jak najlepszego wypełnienia swojej roli. To właśnie godność chrześcijańskiej matki i wychowawczyni musiała stanowić dla tych zacnych frankońskich matron źródło siły w formułowaniu autorytatywnych wskazówek i upomnień. Przybierający na sile perswazyjny ton staje się szczególnie widoczny w następujących po sobie rozdziałach Podręcznika dla Wilhelma. Dhuoda kilkakrotnie przypominała synowi o swoim statusie. Z jednej strony widzimy jej wyraźną świadomość własnej, kobiecej niemożności i marności w konfrontacji ze światem mężczyzn, z drugiej zaś zaskakującą odwagę, gdy do głosu dochodziła kwestia tzw. ,pożytecznego" wychowania synów dla dobra rodu Bernarda, a także całej wspólnoty chrześcijańskiej. Już w prologu dzieła wyraźnie dała znać, co stanowi o sile jej argumentacji:

Ja, Dhuoda, chociaż jestem słabego umysłu i żyję niegodnie pośród godnych [niewiast], to jednak jestem twoją rodzicielką (genitrix), synu mój Wilhelmie i do ciebie teraz słowa mojego podręcznika są kierowane, abyś, [...] jak żywię nadzieję, obciążony ogromem doczesnych i przemijających obowiązków nie zaniedbał, aby często czytać tę niewielką książkę. Ze względu na pamięć o mnie, [i robił z nią to, co niewiasty] ze zwierciadłami, [a dzieci] z grą planszową ${ }^{50}$.

W przywołanym fragmencie zauważalna jest niezwykle silna świadomość kobiecej i matczynej tożsamości, która kierowała Dhuodą. Doskonale znała ona swoje słabe, ale także i mocne strony. Nie miała więc oporów, aby mówić Wilhelmowi o dręczących ją niewieścich niedoskonałościach. Chciała, żeby wiedział, jak bardzo cierpi, jak jest nieszczęśliwa i słaba. Ponad wszystko jednak pragnęła udowodnić pierworodnemu, że niezłomnie trwa w swym matczynym przeznaczeniu. O wadze wypełnianej przez siebie misji przekonywała takimi oto słowami: „I chociaż ciągle słaba jestem niczym cień, mam dla ciebie, synu Wilhelmie, sprawy, które muszę ci oznajmić, to co zdołasz jeszcze bardziej zrozumieć na temat Boga" ${ }^{\prime 51}$.

$\mathrm{Z}$ uwagi na bliską, a także intymną relację z Wilhelmem karolińska autorka w śmiały sposób przydawała sobie różnorodne nobilitujące mia-

50 Liber manualis, Incipit prologus, SCh 225, s. 80: „Dhuoda quanquam in fragili sensu, inter dignas uiuens indigne, tamen genitrix tua, fili Wilhelme, ad te nunc meus sermo dirigitur manualis, ut, [...] ita te obto ut, inter mundanas et saeculares actionum turmas oppressus, hunc libellum a me tibi directum frequenter legere, et, ob, memoriam mei, uelut in speculis atque tabulis ioco, ita non negligas".

51 Liber manualis 1, 4, SCh 225, s. 104: „Adhuc, quanquam fragilis ad umbram, habeo tibi insinuanda, fili Wilhelme, quid de Deo altius ualeas intelligere". 
na, które wskazywały na zakres pełnionych przez nią zadań i posiadanych kompetencji. Zatem zdając sobie sprawę, że w sferze jej matczynych obowiązków bezsprzecznie leży pokrzepianie syna i dodawanie mu otuchy, skonstruowała dla siebie określenie ortatrix, które wywiodła od łacińskiego czasownika hortor ${ }^{52}$. Utworzony w ten sposób rzeczownik oznaczał kobietę, która zachęca, napomina i namawia. Formą swą nieprzypadkowo zbliżony był także do znanego i często używanego przez markizę pojęcia genitrix. Słowotwórcze eksperymenty autorki były zabiegiem w pełni zamierzonym, chodziło o wyraźne zasygnalizowanie przywilejów i uprawnień rodzicielki. Dhuoda była kochającą całym sercem matką (genitrix), co oznaczało także, że pełniła szczególną rolę wspomożycielki swoich dzieci (ortatrix):

Dhuoda, twoje wspomożenie (ortatrix), jest zawsze obecna, synu, gdyby mnie zabrakło, co zaiste nastąpi, masz na pamiątkę tę książeczkę moralną, [w niej] jak gdyby w odbiciu lustra będziesz mógł mnie zobaczyć, czytając umyłem oraz ciałem i modląc się do Boga. Tutaj znajdziesz w pełni to, co mógłbyś usłyszeć ode mnie. Synu, będziesz miał nauczycieli, którzy będą mogli udzielić ci lepszych i pożyteczniejszych wskazówek, lecz oni nie mają statusu równego mojemu, nie mają w piersi serca bardziej płonącego niż ja, twoja matka (genitrix), mój synu pierworodny ${ }^{53}$.

W innym miejscu Podręcznika markiza przedstawiała siebie jako ordinatrix, czyli ta, która porządkuje sprawy syna. Można zauważyć, że w dalszym ciągu oscylowała wokół wyjściowego dla niej pojęcia genitrix. Status rodzicielki implikował więc bardziej szczegółowe godności. Matka była dla swojego potomstwa wspomożycielką, a także jedynego rodzaju moralną ochmistrzynią:

Tak jak tylko mogłam, niczym ochmistrzyni (ordinatrix) starałam się pomagać tobie we wszystkim i uporządkować doczesne wartości, tak abyś mógł stąpać spokojnie i bezpiecznie oraz bez zarzutu, zarówno wtedy, gdy reali-

52 Hortor - 'namawiać, zachęcać, pobudzać, napominać, nalegać, krzepić, dodawać otuchy, błagać, usilnie prosić'.

53 Liber manualis 1, 7, SCh 225, s. 114-115: „Ortatrix tua Dhuoda semper adest, fili, et si defuerim deficiens, quod futurum est, habes hic memoriale libellum moralis, et quasi in picturam speculi, me mente et corpore legendo et Deum deprecando intueri possis, et quid erga me obsequi debeas pleniter inueniri potes. Fili, habebis doctores qui te plura et ampliora utilitatis doceant documenta, sed non aequali conditione, animo ardentis in pectore, sicut ego genitrix tua, fili primogenite". 
zujesz się w czynnym wojskowym życiu, albo też wtedy, gdy [oddajesz się] $\mathrm{z}$ godnością kontemplacji ${ }^{54}$.

W kontekście rozważań nad pozycją arystokratek frankońskich, a także nad społecznymi oczekiwaniami względem pełnionych przez nie edukacyjnych obowiązków, interesującym okazać się może dyskurs na temat podwójnych narodzin, który Dhuoda umieściła w siódmej księdze swojego dydaktycznego dzieła. Zainspirowana nauką św. Augustyna ${ }^{55}$ zapragnęła wyjaśnić Wilhelmowi znaczenie narodzin cielesnych oraz duchowych, które zachodzą w człowieku. Z dumą podkreślała, że tylko ona jest podwójną rodzicielką Wilhelma, jego ciała w momencie narodzin, a także duszy - poprzez kształtowanie charakteru i poglądów: „Natomiast teraz - jako twoja podwójna rodzicielka, duszy i ciała - nie zaprzestanę pouczać cię w jaki sposób - z Bożą pomoca - masz poprowadzić ku doskonałości służbę względem twojej duszy, tak abyś każdego dnia mógł odradzać się w Chrystusie"56.

Narodziny duchowe były, jak wyjaśniała dalej autorka, procesem znacznie doskonalszym i szlachetniejszym aniżeli wydanie na świat samego ciała ${ }^{57}$. A zatem, jak można na tej podstawie wnosić, skutecznie sprawowaną funkcję wychowawczą nad dziećmi rozumiano jako zadanie, które przynosiło niekwestionowany zaszczyt. Tylko matki posiadały przywilej dwukrotnego powołania swoich dzieci do życia. Najpierw je rodząc, a później przysposabiając do służby Bogu oraz innym ludziom. Karolińska autorka zwracała Wilhelmowi uwagę, że ten, kto jest w stanie powtórnie zrodzić dzieci, co częstokroć przebiega przy współudziale bólu odpowiadającego katuszom pierwszego porodu, ów daje im drugie życie. Pozwala bowiem na to, aby ukształtował się w nich Chrystus ${ }^{58}$.

54 Liber manualis 7, 1, SCh 225, s. 298: „Qualitas temporalium, ut, absque reprehensione, tempore dum vivis in militia actuali, sive dignitatis contemplationum, secure et quiete valeas incedere, prout valui ordinatrix tibi astiti in cunctis".

55 O podwójnych narodzinach pisał Augustyn w Tractatus in Johannem $(11,6)$, a także w Sermones $(121,4)$.

56 Liber manualis 7, 1, SCh 225, s. 298: „Nunc vero deinceps militiam animae tuae qualiter, auxiliante Deo, ad summum usque perducas, velut genitrix secunda mente et corpore ut in Christo cotidie renascaris ammonere non cesso".

57 Por. Liber manualis 7, 1, SCh 225, s. 298: „Secundum dicta namque doctorum, duo natiuitates in uno homine esse noscuntur, una carnalis, altera spiritualis, sed nobilior spiritualis quam carnalis" - 'Ponieważ stosownie do zdania uczonych w człowieku rozpoznaje się podwójne narodziny, jedne cielesne i drugie duchowe, przy czym duchowe są szlachetniejsze od cielesnych'.

58 Por. Liber manualis 7, 3, SCh 225, s. 300: „Qualiter homo secundae natiuitatis pluribus possit esse genitor, audi Apostolum: «Filioli mei, quos iterum parturio, donec Christus in uobis firmius formetur» [Ga 4,19]" - 'Posłuchaj Apostoła, w jaki sposób czło- 
Dla Dhuody wzorem idealnych matek, którym z powodzeniem udało się uformować dusze swoich synów, były - znane jej za pośrednictwem licznych hagiografii - rodzicielki męczenników. Namawiała Wilhelma, aby sam czytał o Marcjanilli, matce Celsusa ${ }^{59}$, oraz Auguście, matce Symforiana $^{60}$. Możemy założyć, że wymienione w Liber manualis święte matki stanowiły dla Dhuody nie tylko swoistego rodzaju drogowskaz, ale także i cenną podporę, na której budowała swoje nobilitujące miano mater familias. Prawdziwie świętą żoną oraz wychowawczynią była oczywiście także Monika, matka świętego Augustyna. Reminiscencję jej niezwykłego poświęcenia oraz troski o chrześcijańskie wychowanie syna odnajdujemy najpierw w nauczaniu Herchenefredy, a następnie we wskazówkach udzielanych przez Dhuodę. Przykład cierpliwej, usłużnej, wierzącej i ufającej matki, jaką była Monika ${ }^{61}$, miał niewątpliwy wpływ na obie arystokratki, które kontynuowały utrwaloną i długą tradycję matek-nauczycielek.

\section{Wzorzec chrześcijańskiej matrony według duchownych karolińskich}

Na uwagę zasługuje fakt, że pisma Herchenefredy i Dhuody nie stanowią odosobnionego świadectwa na temat kompetencji frankońskich arystokratek. Dokładna analiza karolińskich źródeł pozwala nam, co istotne, ukonstytuować założenie, że w państwie Franków musiał już od dawna funkcjonować ów pożądany wzorzec chrześcijańskiej matki, który starały się urzeczywistniać w swym życiu wspomniane autorki. Niezwykle istotną wzmiankę na ten temat wnosi spisany pomiędzy 790 a 794 obszerny kapitularz, który znany jest dziejom jako Libri Carolini - Księgi

wiek może być rodzicem wielu dzieci w [ich] drugim życiu: «Dzieci moje, które w bólach powtórnie rodzę, aż Chrystus w was się ukształtuje» (Ga 4,19)’.

59 Celsus, Kelsos (zm. ok. 311) wraz z matką nawrócił się na chrześcijaństwo i wraz z nią zginął męczeńską śmiercią w okresie prześladowań Dioklecjana.

60 Symforian z Autun (zm. ok. 180), skazany na męczeńską śmierć za obronę wiary chrześcijańskiej. Matka miała pocieszać go w trakcie egzekucji słowami, które weszły do prefacji myszy za zmarłych: Vita non tollitur, sed mutatur. Por. Liber manualis 7, 3, SCh 225, s. 300-302: „Lege beatam «Marcianillam», matrem pueri Celsi, et beatam Augustam, matrem sancti Simphoriani, Augustodunensium ciuitem, qualiter primae et secundae natiuitatis genitrices in Christo suis extiterunt prolibus".

61 Por. H. Majkrzak, Święta Monika - wzór chrześcijańskiej żony i matki, „Sympozjum” 32 (2017) s. 258. 
karolińskie. Pismo zredagowane zostało w formie polemicznego traktatu, podejmującego stanowczą i bezpardonową krytykę wobec postanowień soboru nicejskiego II (787). Okazuje się, że na jego łamach nadworni teologowie Karola Wielkiego przywołali - interesującą nas - godność chrześcijańskiej mater familias. Ten zaszczytny tytuł pojawił się w rozdziale, w którym dla kontrastu napiętnowano przywódcza rolę bizantyńskiej cesarzowej Ireny (zm. 803). Karolińskie gremium nie miało najmniejszych wątpliwości, że kobiecie nie przysługują żadne kierownicze kompetencje. Cała wspólnota ucierpiałaby, jak czytamy, gdyby prymat nad nią objęła niewiasta. Co znaczące jednak, istniała przestrzeń, w której kobieta mogła śmiało wystapić w roli mentorki. Chodziło tutaj oczywiście o sprawowanie wychowawczej pieczy nad najbliższymi jej domownikami. W opozycji do skutecznej i roztropnej mater familias Frankowie usytuowali władczą oraz ich zdaniem pozbawioną pokory Irenę, która niestety nie wpisywała się w proklamowany przez Księgi karolińskie ideał kobiecości:

Czym innym jest bowiem, kiedy mater familias wychowuje domowników słowami i przykładami, jeszcze innym, kiedy jakaś [kobieta] - nauczając - jest obecna pośród kapłanów, całego zgromadzenia kościelnego czy też na synodzie powszechnym, podczas gdy zaiste właśnie ta [pierwsza], która zachęca domowników, pragnie uzyskać swój sukces dla ich dobra, ta druga - na zgromadzeniu - zabiega tylko o pragnienie chełpliwej sławy i samej jedynie dumy ${ }^{62}$.

Z zacytowanego fragmentu wynika, że w społeczeństwie karolińskim było obecne, opierające się na dawnym rzymskim ideale matrony, miano chrześcijańskiej mater familias. Pod pojęciem tym krył się wizerunek bogobojnej świeckiej arystokratki, która - wzorem swych rzymskich poprzedniczek (matron) - pozostawała pod władzą męża i traktowana była w kategoriach piastunki moralności. Do przypisanych jej zadań należało rodzenie dzieci, troska o rodzinę oraz utrzymywanie dobrej reputacji męża ${ }^{63}$. Jak zauważyła Valerie Garver, świeckie arystokratki musiały zatem aktywnie uczestniczyć w kształtowaniu i utrwala-

62 Tł. M. Chudzikowska-Wołoszyn. Opus Caroli regis contra synodum (Libri Carolini), red. A. Freeman - P. Meyvaert, MGH, Conc. 2, Suppl. 1, Hannover 1998, s. 389: „Aliud est enim matrem familias domesticos verbis et exemplis erudire, aliud antestibus sive omni ecclesiastico [ordini] vel etiam publicae synodo quaedam [inutilia] docentem interesse, cum videlicet ista, quae domesticos exhortatur, eorum et suum in commune adipisci cupiat profectum, illa vero in con[ventu] ventosae tantum laudis et solius arrogantiae ambiat appetitum".

63 Por. Garver, Women and Aristocratic Culture in the Carolingian World, s. 1. 
niu postaw, poglądów oraz zwyczajów, które trwale naznaczyły kulturę ziem karolińskich ${ }^{64}$.

Społeczne oczekiwania względem kształceniowej roli matek potwierdzone zostały także w powstałych w IX wieku zwierciadłach dla świeckich, które skomponowali męscy rówieśnicy Dhuody. Biskup Jonasz z Orleanu (ur. ok. 780), który znany był ze swej czynnej działalności na rzecz imperium karolińskiego, przekazał w 829 roku hrabiemu Matfrydowi wzorcotwórczy traktat De institutione laicali. Utwór napisany został na zamówienie samego adresata, który jako świeżo poślubiony małżonek skierował do cenionego biskupa prośbę o nakreślenie dlań swoistego rodzaju chrześcijańskiego poradnika małżeńskiego. Jako gorliwy sługa Boży pragnął bowiem uzyskać odpowiedź na ważkie pytanie, w jaki sposób można, podobając się oczywiście Bogu, właściwie wieść rodzinne życie ${ }^{65}$.

Druga księga De institutione laicali zdominowana została wskazówkami z zakresu etyki małżeńskiej. Jonasz zawarł w niej, istotne dla nas, drobne uwagi dotyczące wzorcowych kobiecych cnót, które mężowie winni byli najbardziej u swych żon cenić. Szczególnie pożądanym kobiecym przymiotem, jak czytamy, była wstydliwość, skromność obyczajów (pudicitia) ${ }^{66}$ oraz szlachetność umysłu (decus mentis) ${ }^{67}$. Biskup Orleanu, kierując się wcześniejszą nauką Izydora z Sewilli (zm. 636), przywołał także cztery cechy, które od wieków czyniły kobiety upragnionymi w oczach mężczyzn. Należały do nich pochodzenie, roztropność, majętność oraz piękno ${ }^{68}$. Karoliński duchowny z nich wszystkich najbardziej doceniał roztropność, która od wczesnej ery chrześcijańskiej odnosiła się także do tzw. cnoty domowej ${ }^{69}$, czyli między innymi również do odpowiedzialnego wypełniania obowiązków wychowawczych wobec dzieci. Jonasz napominał, aby rodzice pamiętali o pilnym kształceniu swoich

64 Garver, Women and Aristocratic Culture in the Carolingian World, s. 1.

65 Por. Ionae Aurelianensis episcopi De institutione laicali, Praefatio, PL 106, 121 123: „Tuae nuper strenuitatis litteras suscepi, quibus meam extremitatem commonefecisti, ut tibi citissime et quam brevissime scriberemus qualiter te caeterosque qui uxorio vinculo ligantur, vitam Deo placitam ducere oporteret".

66 Por. De institutione laicali 2, 5, PL 106, 179: „Non sunt igitur in uxoribus divitiae tantum et pulchritudo, sed potius pudicitia, et morum probitas quaerenda”.

67 Por. De institutione laicali 2, 5, PL 106, 178: „Qui ergo magis pulchritudinem corporis, et desiderium voluptatis quam decorem mentis in uxoribus diligunt, audiant quid praefatus Ambrosius im memorato primo dicat [...]".

68 Por. De institutione laicali 2, 12, PL 106, 188-189: „Quatuor quippe sunt, quibus feminae viris appetibiles fiunt, genus, prudentia, divitiae, et pulchritudo". Por. Isidorus Hispalensis, Etymologiae IX 7, 29.

69 Por. Garver, Women and Aristocratic Culture in the Carolingian World, s. 1. 
pociech. Mieli wychowywać je w bojaźni Bożej, nauczać pobożnego życia, a także instruować, jak czcić Boga i szanować swoich rodziców. Przestrzegał, że zaniedbanie tych zadań ściąga na rodzicieli ogromne niebezpieczeństwo ${ }^{70}$. Grzechy popełnione $\mathrm{w}$ dorosłym życiu przez źle wychowane dzieci zostaną, zgodnie z admonicją biskupa Orleanu, przypisane ostatecznie ich rodzicom ${ }^{71}$.

Około 859 roku, czyli już po śmierci Dhuody, powstało zwierciadło De rectoribus christianis mało znanego najprawdopodobniej iryjskiego uczonego Seduliusza Szkota. Dzieło zadedykowane zostało królowi Lotaryngii Lotarowi II (zm. 869). Na jego łamach znajdujemy, znaczący dla analizowanej kwestii, rozdział poświęcony żonie władcy. Seduliusz znacznie rozwinął w nim wspomnianą u Jonasza cnotę roztropności, której mężczyźni mieli szczególnie pragnąć u swoich żon. Roztropność była bowiem probierzem pożyteczności i splendoru małżonki. Pobożny i mądry władca, według podpowiedzi Seduliusza, powinien mieć małżonkę nie tylko szlachetną, piękna i bogatą, lecz także skromna, roztropną oraz posłuszną świętym cnotom ${ }^{72}$. Roztropność okazywała się umiejętnością, która $\mathrm{w}$ doskonały sposób umacniała rodzinną wspólnotę: „,...] pobożna i roztropna kobieta o skromnym wyglądzie i wesołej mowie, umiejętnie skłaniająca się ku pożytecznym sprawom, spokojnie kieruje dziećmi i rodziną [...]"73. Seduliusz Szkot, odnosząc się do idealnego wzorca nobliwej małżonki, wspomniał o jej jeszcze jednym ważnym przymiocie. Chodzi tutaj o unikatową rolę mentorki, którą charakteryzował w następujący sposób: „Wypada zaś, żeby ona [małżonka] nie tylko była związana i podporządkowana swojemu mężowi czystym węzłem małżeńskim, ale żeby zawsze przejawiała skłonność ku świętej rozmowie i pobożności oraz żeby była autorką roztropnych rad"74.

70 Por. De institutione laicali 2, 14, PL 106, 192: „Ut parentes liberos suos diligenter in timore Dei erudiant, docentes eos qualiter caste vivere, Deumque colere, et parentibus honorem debeant impendere. Et quale periculum eis immineat qui id facere negligunt".

71 Por. De institutione laicali 2, 14, PL 106, 193: „[...] quorum peccata parentibus, qui eos in tenera aetate castigare noluerunt, imputari dubium non est".

72 Sedulius Scottus, De rectoribus christianis 5, red. R.W. Dyson, Woodbridge 2010, s. 76-78: „Is ergo perspicaciter procuret ut non solum nobilem pulchram ac divitem, sed castam, prudentem quoque atque in sanctis virtutibus morigeram habeat conjugem".

73 Tł. M. Chudzikowska-Wołoszyn. Por. De rectoribus christianis 5, 78: „,...] casta et prudens mulier, utilibus rebus disciplinabiliter intendens humili facie hilarique sermone, pacifice liberos et familiam regit, [...]".

74 De rectoribus christianis 5, 78: „Talem autem decet non solum viro suo casta copula esseconnexam et subditam, sed pietatis et sanctae conversationis semper ostendere formam, ac prudentium consiliorum esse repertricem". 
W świetle powyższych uwag wyraźnie zauważamy, jakie były męskie oczekiwania w odniesieniu do zadań oraz ról dobrze urodzonych niewiast. Należy podkreślić, że były to oczekiwania formułowane przez kapłanów, które stanowić miały przede wszystkim narzędzie oddziaływania na najwyższe warstwy laikatu. To karolińskie środowiska kościelne stawały się motorem napędowym idei, zgodnie z która obowiązkiem roztropnych arystokratek było kształtowanie zachowań i postaw osób znajdujących się w ich najbliższym otoczeniu. Duchowni wierzyli, że arystokratki mogą w pewnym stopniu przyczynić się do uzdrowienia społecznych konfliktów, które osłabiały karolińskie imperium. Wykształcone i świadome swojej szlacheckiej krwi matres familias były więc postrzegane jako skuteczne orędowniczki kościelnych reform.

\section{Tradycja matek-nauczycielek w pismach Ojców Kościoła}

Herchenefreda oraz Dhuoda potwierdzają, że były w pełni świadome stawianych przed nimi oczekiwań. Kompletnie wpisały się też w opiewany wizerunek dobrej i roztropnej matki, która była autorką wychowania moralnego swoich dzieci. Dydaktyczne pisma obu arystokratek stanowią unikatowy przykład kobiecego wkładu w naprawczy program społeczeństwa i państwa. Są one także niewątpliwym świadectwem trwającej od wielu pokoleń instruktażowej tradycji, która spoczywała na nobliwych mężatkach. Jak wiemy, wzorzec matki-nauczycielki pojawił się już w nauczaniu Jana Chryzostoma (zm. 407), który odnosząc się do przestrzeni chrześcijańskiego wychowania, miał nadać matce rodziny pewien rys pogańskiej mater familias ${ }^{75}$. W ten sposób wyraźnie zarysował wychowawczą rolę matki, której udział w procesie dorastania i kształcenia dzieci stawał się obligatoryjny i dopełniający. Miała ona - w podobny do swego męża sposób - pozostając oczywiście pod jego władzą, dbać o to, aby zarówno córki, jak i synowie dorastali w cnotliwości i skromności ${ }^{76}$.

75 W swoim nauczaniu wprawdzie nie użył klasycznego określenia mater familias, jednak przedstawiona przez niego interpretacja roli matki i małżonki w wielu miejscach zbliża się do pogańskiego modelu matrony. Por. J. Jurkiewicz, Mater familias w nauczaniu św. Jana Chryzostoma, VoxP 53-54 (2009) s. 230.

76 Por. Joannes Chrysostomus, De inani gloria et de educandis liberis 90, SCh 188, Paris 1972, s. 196, tł. W. Kania, Św. Jan Chryzostom, O wychowaniu dzieci, w: Św. Jan Chryzostom, Wybór pism, PSP 13, Warszawa 1974, s. 185: „Niech i matka w podobny sposób trudzi się w wychowaniu swej córki. Przede wszystkim - niech ją oddala od przepychu świata i wszystkiego, za czym gonią hetery. [...] Niech po- 
Postrzegana była przy tym w kategorii strażniczki chrześcijańskiej moralności oraz pobożności ${ }^{77}$.

Potrzebę włączenia matek do programu wychowawczego chrześcijańskich rodzin akcentował także św. Hieronim (zm. ok. 420). Uważał on, że dla dobra Kościoła i jego wspólnoty kobiety jak najbardziej powinny partycypować w tzw. pouczaniu i instruowaniu. Nobilitował więc „słabszą płeć" i obarczał ją odpowiedzialnością za kształcenie młodych i niewinnych dusz, które miały stać się „świątyniami Pana”. W liście do Lety, Rzymianki pochodzącej z patrycjuszowskiego rodu, dał wyraz swojej duszpasterskiej troski o właściwe wychowanie maleńkich dzieci ${ }^{78}$. Pouczał młodą matkę w jaki sposób, krok po kroku, prowadzić córkę ku świętości ${ }^{79}$. Podobne admonicje słał do pobożnej Salwiny, która po śmierci męża samotnie podjęła wychowawczy trud nad swoim potomstwem. Strydończyk nakazywał wdowie, aby całkowicie oddała się opiece nad dziećmi i zadanie to taktowała jako swoje przeznaczenie i misję ${ }^{80}$.

\section{Podsumowanie}

Możemy podsumować więc, że wyznaczona przez Ojców Kościoła wychowawcza rola oraz posłannictwo, które spoczęło na chrześcijań-

wstrzymuje matka syna i córkę od zbytku i pijaństwa - to jest najważniejszy środek do zachowania czystości”.

77 Por. Joannes Chrysostomos, De inani gloria 32, 124, tł. W. Kania, Św. Jan Chryzostom, $O$ wychowaniu dzieci, s. 168: „Zwróć uwagę i matce, aby dała chłopcu te same nauki, również wychowawcy i służącemu. Niech strzegą i uważają, aby żadne złe słowo nie wymknęło się z ust syna i nie przeszło przez złotą bramę".

78 Por. Hieronymus, Epistola CVII ad Laetam de institutione filiae, w: Hieronim ze Strydonu, Listy, t. 3, tł. J. Czuj, Kraków 2011, s. 149-158.

79 Por. Hieronymus, Epistola CVII ad Laetam de institutione filiae 3, s. 150-151: „[...] miałem zamiar skierować słowa do matki, to jest do ciebie, i pouczyć cię, w jaki sposób powinnaś wychowywać naszą Paulę, która wcześniej była poświęcona Chrystosowi, [...]". Hieronim wymieniał szereg szczegółowych zadań, które spoczywały na matce-wychowawczyni. Pouczał Letę, aby nieustannie czuwała nad maleńką Paulą, aby ta nie słuchała ani nie mówiła niczego innego jak ,tylko to, co należy do bojaźni Bożej. Niech nie rozumie brzydkich słów, niech nie zna pieśni świeckich, język niech od młodości nasyca się słodyczą Psalmów".

80 Por. Hieronymus, Epistola LXXIX ad Salvinam, w: Hieronim ze Strydonu, Listy, t. 2, tł. J. Czuj, Kraków 2010, s. 240: „Masz więc, Salwino, dzieci, które powinnaś wychowywać, i możesz być przekonana, że zastąpią ci nieobecnego małżonka. [...] Niemałą jest zasługą w oczach Boga dobrze wychować dzieci”. 
skich matres familias, stały się po kilku kolejnych stuleciach udziałem szlachetnej Herchenefredy oraz Dhuody. Żadna z nich jednak, co istotne, nie próbowała budować swojego autorytetu na przykładach zaczerpniętych z pism pierwszych teologów. Nie wiemy więc, czy autorki były świadome tej długiej, trwającej już od pierwszych wieków chrześcijaństwa tradycji czy też może wypełniały ją bardziej z uwagi na istniejące $\mathrm{w}$ ich rodach wielopokoleniowe zwyczaje. Z całą pewnością jednak, czemu dowodzą przeanalizowane źródła, obie arystokratki w pełni czuły się predestynowane do bycia ,,autorkami roztropnych rad”. Ich wychowawczy status był zatem niekwestionowany i niezastąpiony. Każda $\mathrm{z}$ nich traktowała swą pozycję jako należne Bogu macierzyńskie posłannictwo, które dawało możność służenia swojemu zacnemu rodowi. Dhuoda i Herchenefreda udowodniły, że zadaniem dobrze urodzonych kobiet, które zawierały korzystne małżeństwa, było nie tylko urodzenie spadkobiercy, ale, co ważniejsze, skuteczne uformowanie w nim chrześcijańskiej moralności.

\section{Status and Pedagogical Traditions of the Franconian matres familias on the Example of Herchenefreda (7th Century) and Dhuoda of Septimania $(\dagger$ c. 843)}

(summary)

This article will present the issue of the pedigree position and parental rights, which in the centuries-old tradition have been attended by the Franconian aristocrats. These noble and respectable matrons, though subject to the ruthless power of their husbands, and also representing the natural sexus inferior, had, as it turns out, a kind of power of attorney to take an open voice regarding the moral education of their own sons and successors. These women obtained the status of Christian matres familias. At the same time, they did not lack the conviction of the mission performed for the good of the entire family. From the Kingdom of the Franks, get throught two written testimonies of the so-called maternal educational struggles. Unique evidence of maternal effort that became a sacrifice to God. Representing the seventh-century Herchenefred left three instructive letters for her son Dezyderiusz.Dhuoda from Septymania, living in the middle of the 9th century, wrote a long textbook of right living, which addressed her firstborn Wilhelm. Two aristocratic mothers and two preserved unique female sources, written for sons and successors. These testimonies in a detailed way provide us today with answers to questions related to the status of mothers of that time - the mothers of the Franconian families. What was their strength and allowed for the formulation of courageous and arbitrary admonitions directed to their male heirs? In the article, the author will attempt to approximate the definition of the Franconian mater familiae, which, apart from the ancient tribal tradition, also consisted of adopted biblical and patristic pedagogy. 
Keywords: Dhuoda of Septimania; Herchenefreda; Liber manualis; early medieval paraenesis; education in the Frankish state; Christian mater familias

\title{
Status oraz tradycje wychowawcze frankońskich matres familias na przykładzie Herchenefredy (VII wiek) oraz Dhuody z Septymanii (ok. 803-843)
}

\author{
(streszczenie)
}

Niniejszy artykuł podejmuje problematykę dotyczącą pozycji rodowej oraz uprawnień wychowawczych, które na drodze wielowiekowej tradycji stały się udziałem frankońskich arystokratek. Owe zacne i poważane matrony, podlegające bezwzględnej władzy swych mężów, a także reprezentujące naturalny sexus inferior, posiadały, jak się okazuje, swoistego rodzaju pełnomocnictwo do zabrania otwartego głosu w sprawie moralnego wychowania własnych synów i następców. Kobiety te uzyskały status chrześcijańskich matres familias. Nie brakowało im przy tym przekonania o pełnionej dla dobra całego rodu misji. Z okresu państwa frankońskiego zachowały się dwa pisemne świadectwa tzw. matczynych zmagań wychowawczych. Unikatowe dowody macierzyńskiego trudu, który stawał się ofiarą złożoną Bogu. Reprezentująca początek VII wieku Herchenefreda pozostawiła dla swojego syna Dezyderiusza trzy pouczające listy . Dhuoda z Septymanii, żyjąca w połowie IX wieku, spisała z kolei długi wzorcotwórczy traktat poświęcony prawemu życiu, który zaadresowała do pierworodnego syna Wilhelma. Zachowane instrukcje wychowawcze Herchenefredy oraz Dhuody poświadczają, jakie były oczekiwania społeczne względem frankońskich matron. Okazuje się, że ponosiły one wielką odpowiedzialność za przekazanie swoim dzieciom moralnych idei oraz praktyk. Tym samym zajmowały ważną rolę w budowaniu potęgi rodu swoich małżonków. Oba kobiece świadectwa w szczegółowy sposób dostarczają nam dzisiaj odpowiedzi na pytania związane ze statusem ówczesnych matek - rodzicielek merowińskich i karolińskich rodów. W artykule autorka podejmie próbę przybliżenia definicji frankońskiej mater familias, na którą oprócz pradawnej tradycji plemiennej składała się niewątpliwie także zaadoptowana pedagogia patrystyczna.

Słowa kluczowe: Dhuoda z Septymanii; Herchenefreda; Liber manualis; pareneza wczesnośredniowieczna; wychowanie w państwie Franków; chrześcijańska mater familias

\section{Bibliografia}

\section{Źródła}

Dhuoda, Liber manualis Dhuodane quem ad filium suum transmisit Wilhelmum, w: Manuel pour mon fils, red. P. Riché, tł. B. De Vregille - C. Mondésert, SCh 225, Paryż 1997, s. 66-371.

Epistolae Austrasicae, red. E. Dümmler, MGH, Epp. 3, Berlin 1892, s. 110-153. 
Hieronymus, Epistola CVII ad Laetam de institutione filiae, w: Hieronim ze Strydonu, Listy, t. 3, tł. J. Czuj, Kraków 2011, s. 149-158.

Hieronymus, Epistola LXXIX ad Salvinam, w: Hieronim ze Strydonu, Listy, t. 2, tł. J. Czuj, Kraków 2010, s. 235-245.

Ionae Aurelianensis episcopi De institutione laicali, PL 106, 121-278.

Joannes Chrysostomus, De inani gloria et de educandis liberis, red. A.-M. Malingrey, SCh

188, Paris 1972, tł. W. Kania, Św. Jan Chryzostom, O wychowaniu dzieci, w: Św. Jan

Chryzostom, Wybór pism, PSP 13, Warszawa 1974, s. 157-185.

Joannes Chrysostomus, In epistulam I ad Timotheum homilia, PG 62, 501-600, t1. T. Sinko,

Św. Jan Złotousty, Homilie na Listy Pasterskie św. Pawła i na List do Filemona, Kraków 1949.

Opus Caroli regis contra synodum (Libri Carolini), red. A. Freeman - P. Meyvaert, MGH, Conc. 2, Suppl. 1, Hannover 1998.

Sedulius Scottus, De rectoribus christianis, red. R.W. Dyson, Woodbridge 2010.

Vita Desiderii Cadurcae urbis episcopi, red. B. Krusch, MGH, SS rer. Merov. 4, Hannover 1902, s. 547-602.

\section{Opracowania}

Auerbach E., Język literacki i jego odbiorcy w późnym antyku łacińskim i średniowieczu, t1. R. Urbański, Kraków 2006.

Anton H.H., Fürstenspiegel des frühen und hohen mittelalters, Stuttgart 2006.

Bondurand E., L'education carolingienne: Le Manuel de Dhuoda, Paris 1887.

Brunhölzl F., Geschichte der lateinischen Literatur des Mittelalters, t. 1, Munich 1975.

Duby G., Rycerz, kobieta i ksiądz. Małzeństwo w feudalnej Francji, tł. H. Geremek, Warszawa 1986.

Garver V.L., Women and Aristocratic Culture in the Carolingian World, Ithaca - London 2009.

Hozeski B.W., Herchenefreda, w: An Encyclopedia of Continental Women Writers, t. 1, red. K.M. Wilson, New York - London 1991.

Jurkiewicz J., Mater familias $w$ nauczaniu św. Jana Chryzostoma, VoxP 53-54 (2009) s. $223-231$.

Majkrzak H., Święta Monika - wzór chrześcijańskiej żony i matki, „Sympozjum” 32 (2017) s. 253-264.

Malan R., The Ancestry of Dhuoda, Duchess of Septimania, „The Genealogist” 11/1 (1997) s. $116-126$.

Manitius M., Geschichte der Lateinischen Literatur des Mittelalters, t. 1, München 1959.

Olsen G.W., One Heart and One Soul (Acts 4:32 and 34) in Dhuoda's Manual, „Church History. Studies in Christianity and Culture" 61/1 (1992) s. 23-33.

Riché P., Edukacja i kultura w Europie Zachodniej (VI-VIII w.), tł. M. Radożycka-Paoletti, Warszawa 1995. 
Salin E., La civilization mérovingienne, d'après les sépultures, les textes et le laboratoire, t. 2, Paris 1952.

Stownik łacińsko-polski, t. 4, red. M. Plezia, Warszawa 1999.

Wemple S.F., Women in Frankisch Society: Mariagge and the Cloister 500 to 900, Philadelphia 1981.

Wollasch J., Eine adlige Familie des früher Mittelalters. Ihr Selbstverständnis und ihre Wirklichkeit, „Archiv für Kulturgeschichte” 39 (1957) s. 150-188. 